\title{
Cephalization of the Noosphere: Socio-Philosophical Aspects
}

\author{
Grigory Smirnov
}

\author{
Doctor of Philosophical Sciences, Professor, Ivanovo State University (Ivanovo, Russia) \\ E-mail: gssmirnov@mail.ru \\ https://orcid.org/0000-0002-5797-2121
}

\begin{abstract}
Dmitry Smirnov
Doctor of Philosophical Sciences, Associate Professor, Ivanovo State University (Ivanovo, Russia)

E-mail: dissovet_212@mail.ru

https://orcid.org/0000-0002-0948-7965
\end{abstract}

The article investigates a phenomenon of cephalization of noosphere. Cephalization is presented as a process of the brain development unfolding on numerous forms of living matter; as an adaptation way of the cosmic organism of the Universe. Modern global cephalization is determined by the coevolution of natural and artificial intelligence in the context of the complementarity principle and the correspondence principle. The idea of the artificial intelligence as a continuation of the geological cephalization process is stated. The authors stress its not just biological or biospheric, but also noospheric and cosmic essence. Cephalization of noosphere is depicted as a special supra-social (meta-social, socio-natural) form of civilization development ruled by the cosmic teleology.

Keywords: noosphere; cephalization; global consciousness; semiotic universum; noospheregenesis; synergetics; universal (noospheric) history; Universum; noospheric reality; noospheric universum

Received: April 13, 2018; accepted: August 10, 2018

Philosophy and Cosmology, Volume 22, 2019: 137-143.

https://doi.org/10.29202/phil-cosm/22/12

\section{Introduction}

Specialists in the field of cognitive science state that the person in its cognitive abilities appears as a trinity: a crocodile, a horse and a human. Thus, it shows the historical forms of brain evolution. In fact, Aristotle considered this problem not as cognitivist but as a Universalist (using, strictly speaking, general philosophical background). His "universal evolutionism" portrayed a soul also in three dimensions — "vegetable soul", "animal soul"

(C) Smirnov, Grigory, 2019

(C) Smirnov, Dmitry, 2019 
and "human soul" as it was stated by Aristotle. However, the history of philosophy knows even wider models of reflective abilities, unfolding in the universe. For instance, panpsychism presupposes the self-reflection of the Universum: the Universe acts as a self-observer as well as a self-creator ("following" the Hermetic "similarity" principle). In this sense, the evolution of the Universe's mind appears as a phylogenesis just as the formation of the planetary (mankind) mind appears as ontogenesis. It is easy to see that the ontogenesis of the planetary noosphere proceeds much faster than the mind evolution of the universe [Bazaluk, 2014; Smirnov, 2012]. We can say here metaphorically that the "human mind pregnancy" is similar to the human body pregnancy (in accordance with the Haeckel-Muller law).

The modern cognitology is almost dead and it strangles the culture as well as nature. The modern mind being covered by bifurcation exists in various models of self-identification and self-realization. The modern noosphere "thinks" though the different cognitive trends not only domestic, but also wild animals: suicidal wakes or aggressive sharks. However, the planetary geological thinking is even worst: natural disasters are only the most obvious signs of the biosphere-noosphere informational dynamics.

This situation encourages us to raise the problem of the noospheric safety in the age of global catastrophes. However, we understand it in a different way than the technospheric security. Cognitive synergetics seems to become one of the most important prerequisites of noospheric development in the third millennium [Haken, 2001]. The noospheric humanity appears in this plan as an integral and interconnected semiotic-information universum, which construct self-extracting attractors and search for active forms of pre-established harmony. Therefore, this noospheric universum is in fact a consequence of cognitive pantonomy.

Nevertheless, we can trace the noospheric time arrow. The first comprehension attempts of the noospheric time phenomenon [Dmitrevskaya, 2013] were carried out by Teilhard de Chardin (prolife — life — mind) [Teilhard de Chardin, 1987] and Vladimir Vernadsky (inert substance - bio-inert substance - living substance - living intelligent substance) [Vernadsky 1988; Aksenov, 2010]. Strictly speaking, the present time segment is not noospheric, but actually technospheric. It means that all those who do not serve the modern technosphere become the redundant (unwanted) people. As a matter of fact the human mind is increasingly displacing by the computer reasoning with its own limitations in cognitive potential and cognitive resources. Of course, the techno-thinking noosphere as a stage in the human mind development is quite natural. However, the institutional absolutization of this transitory form of noospheregenesis can prove extremely destructive [Smirnov, 2010; Krichevsky, 2017].

The near future is the time of a cognitive human revolution. Its essence is in overcoming the archetypes of all-devouring crocodile as well as unconsciously working horse through the cognitive blast. To tell the truth, cognitive outbreak expects not only an information explosion. Moreover, it seems that they are not so much friends as enemies: disequilibrium and disharmony of the cognitive universe create the dissonance of the noospheric reality [Smirnov, 1998].

\section{The roots and the routes of the cephalization idea}

We can trace the idea of the noospheric cephalization almost in every time of history. For instance, Hermetic principle of similarity is the most convincing example of the guess that the brain is the main sensitivity of the universe. Plato has preserved it for the modern humanity in the notion "Universe as the Living Cosmos". Such an interpretation of the living and inanimate matter interrelations assumes a cosmoplanetary organismic integrity worldview. 
However, cosmic epistemology does not move outside the philosophy, it only immeasurably expand the epistemological space of human existence. Thus, Vladimir Vernadsky's idea of the transition of the biosphere into noosphere [Vernadsky, 1991] turns out to have the same meaning as Plato's idea, but in completely different circumstances. In our opinion, this understanding model is heuristic for understanding the processes taking place in the emerging global humanity.

The philosophy of universal evolutionism [Moiseev, 2001; Ursul, 2018], based on noospheric ideas, discovers the co-evolution processes in the system "Man - Society Nature" as the greatest possible, embraced by science (and by consciousness) integrity. Here, the agnostic paradox ("the more you know, the more you do not know", or "the more you know, the less you know") is overcoming just at the expense of anthropological attainment of the universal being. Only if we go beyond the old, previous system, it becomes possible to rethink the former amplitude of physical and spiritual immersion in being. This is how Gödel's theorem of incompleteness works in the anthropological context: the way out of this cognitive impasse is usually performed through induction, analogy (as a kind of extended induction, in which the conclusion is not drawn from one single judgment, but through the similarity of several individual judgments). Let us stress here that the criterion of a conscious designation of the environment for each person is different, and it is determined by the specificity of cosmo-genetic, bio-genetic, socio-genetic and cultural-genetic heredity.

\section{Science for the cephalization paradigm}

The Indian philosophical tradition shows that each person is a kind of eyes and ears of the universe: the universe feels itself through people who are inseparable from the body. From a philosophical point of view, this situation states the problem of comprehension of the huge organism by the cell. Even a nerve cell cannot have complete information about the body. This level of information about the organism is given to the body through the brain, which in this case seems to be a system larger than the body itself. In this respect the ecological processes of living and non-living matter interaction taking place in the human body are of no less importance than field relations [Bazaluk, 2016], because they can turn out to be system-forming.

The cosmos of the human body - 300 trillion cells, 100 billion nerve cells, 15 billion neurons. Biosphere (noospheric) space - 15 billion people on the planet Earth (according to Sergey Kapitsa estimates, the world population should not exceed 11 billion people [Kapitsa, 2012]). In this context, the human brain, which controls the body, is quantitatively similar to the possible human structure of the noosphere. It turns our reflection to ethologic problem - how to build relationships between people; is there a similarity between human communication interactions and interactions between neurons in the logic of the living matter evolution.

The analysis of Vladimir Vernadsky's works, devoted to the processes of cephalization ("term that indicates an increase in mass and in the organization of the organism's brain in the process of evolution"), shows that this principle is one "among the 20 most important empirical generalizations of higher rank" [Aksenov, 2010: 720]. Thus, cephalization as a process of the brain development unfolding on numerous forms of living matter, is not just a biological or biospheric process. It is a cosmic process: it is an adaptation way of the cosmic organism of the Universe. Cephalization of noosphere at the same time is a special supra-social (meta-social, socio-natural) form of civilization development that has cosmic teleology. 


\section{Biological cephalization vs Social cephalization}

The historical process of the human development and its analysis allows us to trace the ecological evolution of the Reason (Mind) on our planet. At first glance, it is the task of anthropology (including philosophical one), but in reality the completeness of the complexity is provided by biospherology and noospherology as disciplines that claim to be the ultimate synthetic. (It seems that this complexity is much wider than the aggregation of NBIC: nano-, bio-, info-, cogito-. As a matter of fact ecology is not included in the system of priorities, and biology, as can be seen from the context, is to a certain extent limited by "great genetics".) The evolution of Homo sapiens shows that the biological cephalization actually degenerated into social one and acts as a specific form of socialization.

In the twentieth century it became clear that along with the economic cephalization, which was always a leading socio-cultural factor (this idea was clearly expressed by Friedrich Engels in his work "The Part Played by Labour in the Transition from Ape to Man"; and Karl Marx in "Capital" has opened its institutional and organizational forms), the social cephalization and techno one have developed. As well as along with the forms of national and regional cephalization, a model for the global mankind cephalization have been raised. In this sense, the cephalization of civilization appears as one of the central problems of social philosophy as a whole.

\section{Cephalization: post-non-classical discourse}

Post-non-classical science studies an expanded field of human cosmoplanetary being. Hermetic dimensionality of philosophy allows carrying out a reflection (a kind of ecoreflection) in three parallel discourses, on three levels of the universe's being. For instance, Vladimir Vernadsky considered the ontological trinity as a connection of the microcosm, biosphere and cosmos, while he believed that only scientific research of the biospheric reality is available. Now it is possible to build scientific travels to other realities: not only real ones, but also virtual ones, moreover, the space of meta-virtuality - the hyper-thin worlds in the reality of our "habitual" dimension — is forming.

Subtle (slim) field universe structures, determine the features of nature organization and the brain device structure, are accessible to man precisely through the brain as an organ of the "universum sense" (Il'ya Lapshin), which is not yet given to everyone, but discovered as a process of its evolutionary development. In this context, Aleksandr Zinoviev's idea about the anthropohill (human anthill) [Zinoviev, 2000] may not only have a sociological or sociophilosophical meaning, but also a cosmic one. The modern mankind from this point of view can be considered by its cognitive possibilities as an anthill, as well as each person can be presented as an universal ant, whose cognitive capabilities are extremely small compared to the "universal man").

\section{Institutions of cephalization: noospheric discourse}

Cephalization of human civilization in the context of noospheric self-organization can be represented as the process of the collective mind unfolding. Collective mind, in its initial forms, is some kind of a state mechanism that also evolves in the course of historical development. In other forms, it unfolds as the complex social self-organization, which sometimes opposes state power, but sometimes, transforms in the process of struggle in the state power itself. As a matter of fact state power and civil society can be represented as left- 
hemispheric and right-hemispheric ways of mastering and regulating of socio-cultural reality. Social dynamics is the result of their synergistic confrontation.

At the same time, the modes of left and right hemisphere are quite diverse. Hermetic tradition, as well as Chinese one, states such a correlation in the principle of "sex". In fact, there is no greater complementarity in the system of social being than the complementarity of the male and female in the context of sex (biological) and gender (social). The main geopolitical relation of water and land, the religious attitude of the celestial and terrestrial, as well as the economic relation of the East and West, the South and the North also belong to such additional types.

An important variety of "hemispherity" can serve as a geographical division of the globe to the western and eastern, southern and northern hemispheres. In geopolitical and cultural matters, the hemispheric "holistic system" has a significant influence over the world history. Planetary continentality is very important for understanding the processes of cephalization, unfolding in the noospheric historical time. The Haeckel-Muller law — "ontogenesis repeats phylogenesis" - makes it possible to understand that the structure of the brain reflects processes that take place not only in living matter, but also in stagnant matter, which includes cosmos, understood as inanimate matter. An even more representative version is related to how the structures of space manifest themselves in the system of social relations, in general models of civilization development. It may be called the civilization's cephalization.

The features of the world historical process show that the process of cephalization of the noosphere has passed and passes within the framework of rather complex transformational and catastrophic circumstances [Smirnov, 2015]. Let us look over some of the possible similarity of cephalization in the biological sense and cephalization in the social (noospheric) sense. At first glance, this case is placed in the framework of the traditional positivist approach, for we try to transfer biological patterns to the laws of social development. Nevertheless, such an option is heuristic and productive due to the variety of empirical operationality. However, in the problem area, identified above, a more sophisticated form of complexity is needed to obtain new representative results. It seems that in this case the methodological power of Russian cosmism is required to establish a correlation between the development of "living matter and intellect on the planet Earth" [Kaznacheev \& Trofimov, 2004].

\section{Two (poly) hemispherity of the noosphere brain: science, religion, philosophy and art}

The history of mankind shows that the most important "spiritual" hemispheres of the brain of the noosphere are the Church (from the ancient priests organizations to modern confessional forms) and the University (as a form of secular organization of global knowledge). Church in the history of human civilization appears as one of the earliest forms of institutional cephalization. Church builds mainly figurative (figurative-behavioral), while the university — verbal-logical (scientific and general scientific) models of reality. The process of knowledge and consciousness complementarity - the formation of integral knowledge - is manifested in the unity of science and religion. Moreover, the brain of the modern noosphere appears as a quad-core processor, in which science and religion as well as philosophy and art carry out their simultaneous processes. 


\section{Semiotic approach to social cephalization}

The noosphere's cephalization was carried out according to the formational format. The primitive society used the tribal structure of the mind: there worked not only mythological consciousness, but also the elders' ordinary consciousness. A leap forward in the cephalization of noosphere is associated with the emergence of the first civilizations: the writing and the urban environment have created an organization similar to an axon body connected to other axons (city-policies) through "dendrite roads". In this noosphere-semiotic (communicationsignification) system, individuals performed the exchanging functions (exchanging matter, energy and information) both within the city-policy and in relation to other systems. Civilization thus builds a complex social-semiotic network, which is very similar to the nervous system.

The specificity of this kind of socio-cultural cephalization was directly related to the peculiarities of linguistic interaction: the different and dissimilar human substances sought and found the ways of communication that provided the formation of a semiotic unity. Such an emerging connection, eventually forming a semiotic universe, is shown in the works of Vyacheslav Ivanov [Ivanov, 2012]. Semiotic effectiveness proved to be the most important factor in the survival of civilization, while in the past the most effective were simple rigid mechanistic forms of information transmission, where the "chain semiotic reaction" was carried out with the least distortion and high efficiency. At the same time, it turned out that in terms of biological evolution, autocratic semiotic dominance is extremely vulnerable.

Therefore, for several thousand years models of national cephalization were formed: each of them defended its effectiveness and priority. The paradox is that some ethno-national formations wanted to prove their "chosenness" not so much by the power of the mind and semiotic resources as by bare power [Dugin, 2014]. However, this in fact indicates a semiotic weakness and degradation, which ultimately leads to the destruction of any society. The history of Russia shows well that the semiotic potential appears as the main resource of survival.

\section{Cephalization as the law of the universal (noospheric) history}

The imperfection of the modern human noosphere depends largely on the imperfection of the processes of social cephalization. Internet-cephalization is also a prerequisite for the further development of a universal total linking among all members of the human community. Such a kind of post-non-classical cephalization represents the completion of the classical and non-classical stages of cephalization.

Modern society - it does not matter how to call it: "capitalist", "consumer" or "super-consumer" - is a deeply sick and extremely non-ecological society. In this sense, cephalization takes on unexpected forms: its "cosmic will" is stronger than the material and economic processes, which for a long time set not only history understanding, but also its real being. Cephalization in the context of the universal history can be considered as its main law. Using the language of postnonclassicism, it is an attractor of the process of self-organization in the space-planetary system "Man - Society - Nature". Universal (noospheric) history [Nazaretyan, 2015; Smirnov, 2012a] is the process of biological and social cephalization (in the forms that we know today), but, undoubtedly, forms of noospheric cephalization, not yet fully manifested, are also unfold. 


\section{References}

Aksenov, Genady. Comments, in: Vernadsky Vladimir. Selected Works. Moscow: ROSSPEN, 2010: 663-729 (In Russian).

Bazaluk, Oleg. The Basic Postulates of the Universal Evolution Model "Evolving matter". Philosophy and Cosmology. Vol. 14, 2015: 11-20 (In Russian).

Bazaluk, Oleg. The Philosophy of Cosmos: the Place of Human at the Scale of Earth and Cosmos. Chapter One. Philosophy and Cosmology. Vol. 16, 2016: 28-42 (In Russian).

Dmitrevskaya, Irina. The idea of the noospheric man and the premise knowledge. Noospheric Studies. Vol. 3 (5), 2013: 33-55 (In Russian).

Dugin, Alexandr. Noomahiya: wars of the mind. The Logos of Europe: a Mediterranean civilization in time and space. Moscow: Academic Project, 2014 (In Russian).

Haken, German. Principles of the brain: a synergistic approach to brain activity, behavior and cognitive activity. Moscow: Peer Se, 2001 (In Russian).

Ivanov, Vyacheslav. Expediency of man. Novaya Gazeta. Vol. 92, 2012: 20-21 (In Russian).

Kapitsa, Sergey. Paradoxes of growth: The laws of human development. Moscow: Alpina non-fiction. 2012 (In Russian).

Kaznacheev, Vlail, and Trofimov, Alexandr. Essays on the nature of living matter and intelligence on the planet Earth: problems of cosmoplanetary ecology. Novosibirsk: Science, 2004 (In Russian).

Krichevsky, Sergey. Cosmic Humanity: Utopia, Realities, Prospects. Future Human Image. Volume 7, 2017: 50-70 (In Russian).

Moiseev, Nikita. Universum. Information. Society. Moscow: Sustainable world, 2001 (In Russian).

Nazaretyan, Akop. Mega-History and the $21^{\text {st }}$ century singularity puzzle. Philosophy and Cosmology. Vol. 15, 2015: 84-98.

Smirnov, Grigory. Cerealization of the noosphere: the evolution of a reasonable substance at the turn of the millennium. Bulletin of the Ivanovo State University. Series: The humanities. Issue. 2, 2012: 17-30 (In Russian).

Smirnov, Grigory. Education of the noosphere: philosophical and methodological problems. Ivanovo: Ivan. state. univ., 2015 (In Russian).

Smirnov, Grigory. Noosphere in the Age of Global Catastrophes. Bulletin of the Ivanovo State University. Series: The humanities. Issue. 2, 2010: 74-92 (In Russian).

Smirnov, Grigory. Noospheric consciousness and noospheric reality: philosophical \& culturological problems of the noospheric universe. Ivanovo: Ivan. state. univ., 1998 (In Russian).

Smirnov, Dmitry. Noospheric idea and noospheric history: introduction into universum cliosophy. Ivanovo: Ivan. state. univ., 2012a (In Russian).

Teilhard de Chardin, Pierre. The phenomenon of man. Moscow: Science, 1987 (In Russian).

Ursul, Arkady and Ursul, Tatiana. Universal (Global) Evolutionism. Philosophy and Cosmology. Vol. 20, 2018: 33-41. https://doi.org/10.29202/phil-cosm/20/3

Vernadsky, Vladimir. Scientific thought as a planetary phenomenon, in: Vernadsky Vladimir. Biosphere and noosphere. Moscow: Rolf, 2002: 242-470 (In Russian).

Vernadsky, Vladimir. Space and time in animate and inanimate nature, in: Vernadsky Vladimir. Philosophical thoughts of a naturalist. Moscow: Nauka, 1988: 210-384 (In Russian).

Zinoviev, Alexandr. On the way to the superexchange. Moscow: Tsentrpoligraf, 2000 (In Russian). 